\title{
End Point Polymerase Chain Reaction for Porcine Detection on Food Product of UIN Sunan Ampel Surabaya Canteen
}

\author{
Saiku Rokhim ${ }^{1}$, Inggrit Tyautari ${ }^{2}$, M. Aliffiyan Firmansyah ${ }^{3,}$ Yuanita Rachmawati ${ }^{4 *}$ \\ ${ }^{1,2,3}$ Department of Biology, Faculty of Science and Technology, UIN Sunan Ampel Surabaya, \\ Jl. Ahmad Yani No. 117, Surabaya, Indonesia \\ ${ }^{4}$ Halal Center, UIN Sunan Ampel Surabaya, Jl. Ahmad Yani No. 117, Surabaya, Indonesia \\ e-mail: saiku_rokhim@uinsby.ac.id ${ }^{1}$, inggrittyautari@gmail.com ${ }^{2}$, allifianfirmansyah@gmail.com ${ }^{3}$, \\ yuanitarhartono@uinsby.ac.id*4
}

*Corresponding Author

Received: January 28, 2021; Accepted: February 25, 2021

\begin{abstract}
Halal food means food that permitted under Islamic law and fulfills about requirements. The absence of information about halal food contained in UIN Sunan Ampel Surabaya (UINSA) campus area causes related research to be carried out. This study aims to determine the porcine DNA contamination on food around UINSA area using molecular technology. Twenty two samples used were foods that contain meat and may contain pork obtained from canteens around UINSA area, analyzed using Polymerase Chain Reaction (PCR) method. The analysis was started with DNA isolation of 22 food samples, electrophoresis, PCR, then visualization gel electrophoresis. Primer gene coding for cytochrome $b(c y t b)$ which produces $149 \mathrm{bp}$ of DNA fragments. The results showed that no porcine contamination in 22 food samples, while the positive control showed a band of $149 \mathrm{bp}$. End point PCR method potentially to detect porcine DNA contaminants in food products around UINSA. Therefore the food is halal and safe for consumption.

Keywords: end point PCR, pig cyt b gene, porcine detection, UIN Sunan Ampel Surabaya
\end{abstract}

\section{Introduction}

Awareness about religious community of Indonesian Muslim in last decade has grown increasingly. As a consequence, every problem, discovery, or new activity is a product of this progress. The problem with Indonesian Muslims is large number of food products in various processed forms. Halal is an absolute requirement for every Muslim to consume a food. One of halal concept is that food must not contain pork or its derivatives (Asy'ari, 2011). Some meat-based food products were found to be mixed with pork, especially beef. Mixing pork aims to reduce production costs because price of pork is relatively cheap than real beef (Adzakiyyi et al., 2020). Therefore, detection of pork contamination in food products is necessary to protect consumers.

One of educational institutions in Surabaya area that is Islamic area and surrounded by food producers and seller is UIN Sunan Ampel Surabaya. There is not yet information regarding about halal food contained on UINSA campus canteen, makes it necessary to conduct research about halal food products information that sold by traders in the area. Canteen is defined as a space where drinks and food are sold. Food and beverages wich are sold in UINSA canteen must be free from biological, chemical contaminants that can harm, endanger, and not conflict with religions and cultures.

According to Baihaqi et al. (2019) some of food produced by micro-entrepreneurs still uses general meat grinding in market which can cause mixing of various types of meat from other customers. Products that have been given a mixture of pork are very difficult to differentiated, because the meat is mashed and then mixed with other ingredients. It is possible that the sellers in the UIN Sunan Ampel Surabaya canteen also process processed meat food in the general market mill. In this globalization era, there have been many foods that ignore food safety and halal products. Several studies have reported bastosoytone which is derived from pork (Wardani \& Sari, 2015).

Porcine contamination can be detected using End Point PCR Method. The method analysis by amplifying target DNA very advantageous because it can be found in all cell types with identical and stable genetic information (Yusuf, 2010). DNA duplication is assisted by enzymes and a pair of primers that specific to multiplied target DNA. The components that must be present in PCR process 
include DNA template that will be multiplied, primer oligonucleotides that used to stick DNA synthesis, deoxyribonucleotide triphosphate (dNTP), consisting of dATP, dCTP, dGTP, dTTP, and DNA polymerase enzyme that catalyze synthesis reactions and some buffer compounds (Fibriana, Widianti, \& Retnoningsih, 2010).

PCR method incubated the samples at three different temperatures, namely denaturate pieces of DNA at a temperature of $90-95^{\circ} \mathrm{C}$, anneal to DNA template at $40-60^{\circ} \mathrm{C}$, and extention at $70-75^{\circ} \mathrm{C}$. These stages are repeated 25-35 cycles. At the end of PCR process, the results are stored at $4^{\circ} \mathrm{C}$. One of the important factors affecting PCR-based molecular quality is the selection of right primers (Sulandari \& Zein, 2003).

Research about identification of meat types has been carried out by several researchers using mitochondrial DNA. The genes that most often used as markers for animal or meat types include cytochrome $\mathrm{b}(c y t b)$. Some researchers have used cytochrome $\mathrm{b}(c y t b)$ gene to distinguish material from different animal species. Sequence variation in $c y t b$ causes this gene widely used as a marker for grouping animal species. The peculiarities of $c y t b$ gene include almost same areas for all types of animals, but there are also regions that are specific to each type of animal (Primasari, 2011). The use of pig cyt $b$ gene for detection has been widely used in research. Pig $c y t b$ gene is very sensitive and accurate to detect whether a sample contains pig components or not. As research conducted by Ali et al. (2012), Yusop et al. (2012), Kumar et al. (2014), This study aims to determine PCR technique to detect contaminants and porcine in food products around UIN Sunan Ampel Surabaya.

\section{Materials and Methods}

Research was conducted in three months September - November 2017 in Integrated Laboratory (Genetics and Tissue Culture Laboratory) of UIN Sunan Ampel Surabaya. The tools used in this study were a spectrophotometer (Biochrom Biodrop-DUO), thermocycler (Labnet MultiGene Optimax), microcentrifuge (Thermo Scientific Heraeus Fresco 21), electrophoresis (Mupid2Plus), hot plate, analytical balance, microtube, spatula, micropipette and vortex, Enduro GDS-1302 gel documentation.

Materials that used in this research were foods that contain meat in the form of sausage, cornet beef, meatballs, noodles with meat, krengsengan (one kind of meat processed food), and food that may contain pork: halal unlabelled nori and samyang oil obtained from UINSA canteen. Other materials were also used such as Universal DNA Isolation Kit of Wizard Promega: Nuclei Lysis solution; RNAse; protein precipitation solution; DNA Rehydration Solution, isopropanol, 96\% ethanol, Go Taq ${ }^{\circledR}$ Green Master mix, nuclease free water, agarose gel, DNA Diamond nuclei acid dye, buffer, loading dye, benchtop $100 \mathrm{bp}$ ladder, and Forward and Reverse primers. The Sequences of primer shown in Table 1.

Table 1. Primer sequences

\begin{tabular}{ccc}
\hline \multicolumn{1}{c}{ Oligonucleotide } & Amplicon \\
\hline Forward primer & 5' CTACGGGTCTGTTCCGTTGG 3' & $149 \mathrm{bp}$ \\
Reverse Primer & 5' ATGAAACATTGGAGTAGTCCTACTATTTACC 3' & 149 \\
\hline
\end{tabular}

\subsection{Sample preparation}

Samples were collected from 22 foods consisting of foods that contain meat and may contain pork in UINSA canteen including food seller in UINSA and minimarkets in UINSA. Sampling was conducted on September 14, 2017. The sample was weighed as much as $50 \mathrm{mg}$, placed on aluminum foil and labeled. Samples were stored in the freezer at $-20^{\circ} \mathrm{C}$.

\subsection{Extraction of DNA}

Samples were put into a $1.5 \mathrm{~mL}$ microtube, added $600 \mu \mathrm{L}$ of Nuclei Lysis Solution, vortexed for 10 seconds and incubated at $65^{\circ} \mathrm{C}$ for 30 minutes. Added $3 \mu \mathrm{L}$ of RNAse Solution, vortexed for 10 seconds, incubated at $37^{\circ} \mathrm{C}$ for 30 minutes and cooled in cooler for 5 minutes. Then $200 \mu \mathrm{L}$ of Protein Precipitation Solution was added, vortexed for 10 seconds, cooled for 5 minutes and centrifuged $15000 \times \mathrm{g} *$ for 4 minutes. Supernatant was added with $600 \mu \mathrm{L}$ of isopropanol, shaken and centrifuged $15000 \times \mathrm{g}^{*}$ for 1 minute, then supernatant was removed, added $600 \mu \mathrm{L}$ of $70 \%$ ethanol, and again centrifuged $17000 \times \mathrm{g}^{*}$ for 1 minute, removed the ethanol, tube was dried at room temperature, and $100 \mu \mathrm{L}$ of DNA was added. rehydration solution. 


\subsection{PCR Amplification}

PCR amplified using GoTaq Green protocol and thermocycler tool. The reaction component was $25 \mu \mathrm{L}$, consisting of $2.5 \mu \mathrm{L}$ of DNA sample, $1 \mu \mathrm{L}$ of forward primer, $1 \mu \mathrm{L}$ of reverse primer, 12.5 $\mu \mathrm{L}$ of GoTaq Green, and $8 \mu \mathrm{L}$ of Nuclease Free Water. PCR running with temperature and time shown in Table 2.

Table 2. PCR Temperature and Time

\begin{tabular}{cccccc}
\hline Predenaturation & Denaturation & Annealing & Extention & Post extetion & Cycle \\
\hline $95^{\circ} \mathrm{C}$ & $95^{\circ} \mathrm{C}$ & $60^{\circ} \mathrm{C}$ & $72^{\circ} \mathrm{C}$ & $72^{\circ} \mathrm{C}$ & \multirow{2}{*}{$40 \times$} \\
$5 \mathrm{~m}$ & $45 \mathrm{~s}$ & $45 \mathrm{~s}$ & $40 \mathrm{~s}$ & $5 \mathrm{~m}$ & \\
\hline
\end{tabular}

\subsection{Electrophoresis and Visualization}

PCR results were visualization by electroforesis with $2 \%(\mathrm{w} / \mathrm{v})$ agarose concentration in TAE $1 \times$ buffer solution at a voltage of 50 volts for 75 minutes. Electrophoresis was carried out by placing agarose gel in an electrophoresis device that was filled with $100 \mathrm{~mL}$ of TAE $1 \times$ buffer solution, as many as $5 \mu \mathrm{L}$ of leader were put in $1^{\text {st }}$ and $12^{\text {th }}$ order wells, and entered as much as $5 \mu \mathrm{L}$ of PCR sample results. The results were visualized using the gel documentation.

\section{Results and Discussion}

Sampling was carried out by purpossive methods. Isolated genomic DNA was known by measuring the concentration of DNA using a Biodrop Spectrophotometer. The results of DNA concentration data for each sample can be seen in Table 3 .

\begin{tabular}{ccr} 
Table 3. DNA Concentration & \\
\hline Code & Sample & DNA Concentration $(\mu \mathrm{g} / \mathrm{mL})$ \\
\hline 1 & Meatball 1 & 4.699 \\
2 & Meatball 2 & 5.622 \\
3 & Meatball 3 & 23.270 \\
4 & Meatball 4 & 2.945 \\
5 & Meatball 5 & 9.975 \\
6 & Meatball 6 & 6.452 \\
7 & Meatball 7 & 16.160 \\
8 & Meatball 8 & 4.568 \\
9 & Meatball 9 & 2.844 \\
10 & Meatball 10 & 13.700 \\
11 & Meatball 11 & 21.030 \\
12 & Cornet Beef & 13.410 \\
13 & Grilled Sausage & 9.581 \\
14 & Grilled Meatball & 7.324 \\
15 & Sausage 1 & 17.540 \\
16 & Sausage 2 & 20.470 \\
17 & Krengsengan 1 & 10.400 \\
18 & Krengsengan 2 & 7.187 \\
19 & Fried Sausage & 5.987 \\
20 & Noodle with Meat & 8.067 \\
21 & Halal unlabelled Nori & 26.050 \\
22 & Samyang oil & 18.280 \\
\hline & &
\end{tabular}


Concentration of DNA obtained was very diverse. Concentration was used as a reference to continue or not the PCR amplification process. The highest concentration was sample with code 21 from Halal unlabelled Nori of 26.050 and the lowest DNA concentration was sample with code 4 from meatballs 4 of 2.945. The reason for using nori as a sample is that it is possible that the nori was seasoned with non-halal ingredients, such as a flavoring ingredient from pork. DNA isolated can be used for PCR amplification as indicated by its large enough concentration value. This value indicates that Promega wizard genomic Purification kit is a good kit for DNA extraction from food processed samples.

According to Monteil-Sosa et al. (2000), cyt $b$ primers are universal primers that amplifying $c y t$ $b$ gene on 149 bp. Electrophoresis result then visualized by UV light on Gel Documentation. The results of DNA fragments length observation from electrophoresis are shown in Figure 1. and Figure 2. PCR visualization results for 22 samples (Figure 1.) showed that there were no bands at $149 \mathrm{bp}$ location. It showed that there was no cyt $b$ primer attached to isolated DNA. So that all totaling 22 samples showed negative results.

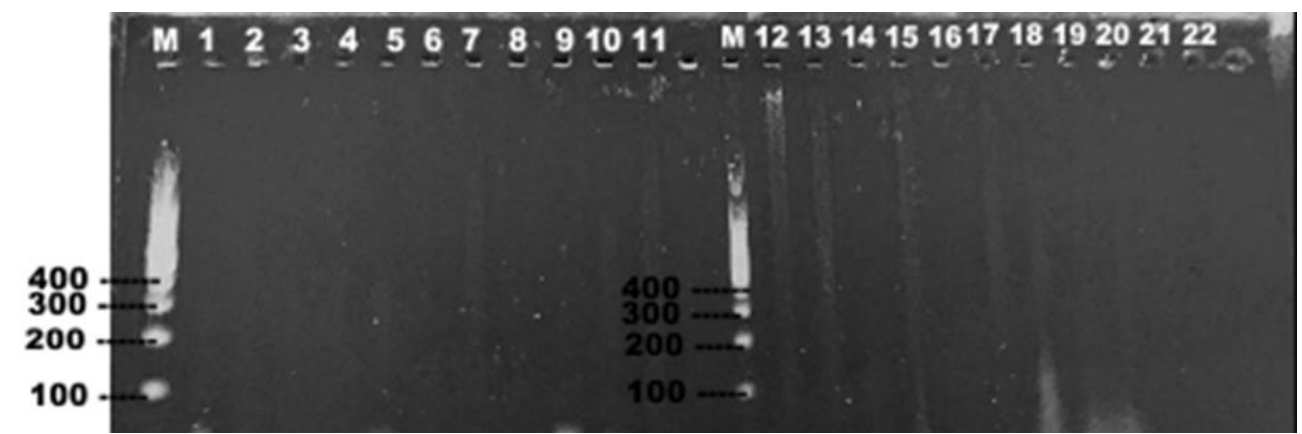

Figure 1. Visualization of DNA Amplification of 22 Processed Food Samples

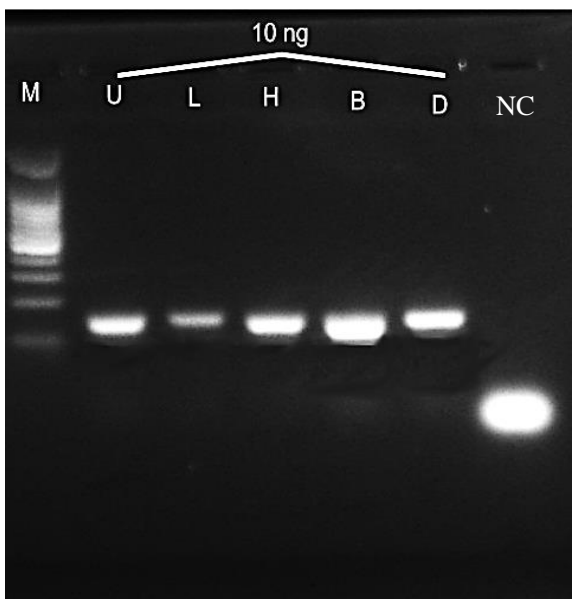

Figure 2. Visualization of DNA Amplifiaction of Positive Control Sample and Negative Control Description: M: Marker Bench Top 100bp; U: Pig Intestine; L: Pig Lard; B: Pig Blood; D: Pig Meat; NC: Negative Control

Sample that used in this research is a group of food products that contain meat in the form of sausage, cornet beef, meatballs, noodles with meat, krengsengan (one kind of meat processed food), and food that may contain pork in the form of halal unlabelled nori and samyang oil obtained from UINSA canteen. The reason for using nori as a sample is that it is possible that the nori was seasoned with non-halal ingredients, such as a flavoring ingredient from pork. Similar to nori, samyang oil can also contain pork. Pork material contaminants can occur during preparation process, manufacture and serving. Sausage and meatballs are processed meat products commonly used as additives in food. Many people choose it because it is easy to get, easy to store and easy to process. Difference between pork and beef can be seen based on color, meat fiber, type of fat, aroma and texture. Pork color is paler than beef and closer to chicken meat color (Puspitasari, Elfidasari, \& Perdana, 2019). However, mixed pork is generally smeared with cow's blood for camouflage. Pork fiber looks faint and tenuous. Mixing pork and beef can cause some problem especially if it has become a processed meat product. 
Consumers become difficult to determine it. For this reason, carefulness in choosing meat by paying attention to existing characteristics is important to learn. Mapping the existence of pork contamination is one source information so that consumers avoid mistakes and are guaranteed about halal food products.

Detection of porcine contaminant in processed food samples derived from canteen in UIN Sunan Ampel Surabaya using PCR begins with DNA extraction in all samples. DNA extraction using wizard genomic DNA purification kit. To ensure PCR amplification process, extracted DNA was measured DNA concentration using spectrophotometer, and then performed PCR amplification with cyt $b$ Genus Sus primer. Amplicon genome were visualized on gel documentation. DNA isolation principal to destruction and purification. Destruction can be done physically by grinding, chemically with chemical reagents, or biologically with enzymes. The purpose of destruction is to damage cells and their organelle membranes, so that cell lysis and DNA can be isolated (Fatchiyah, Widyarti, \& Rahayu, 2011). DNA purification carried out to separate DNA from its impurities in the form of fat, carbohydrates, and proteins. Amplification PCR method used 149 bp from Genus Sus $c y t b$ primers. The order of primer sequences shown in table 1 . Forward primer sequence that goes forward in the PCR amplification process, and a reverse primer sequence that goes backwards in the PCR amplification (Sulandari \& Zein, 2003). Before doing PCR, it is necessary to measure the concentration of DNA to determine the feasibility of DNA for PCR.

PCR has 3 main stages with specified temperature and time settings. The first stage is denaturation, where the DNA fragments are bonded so that become a singlestrain at $95^{\circ} \mathrm{C}$ for 5 minutes. Next, annealing step, attaching the forward and reverse primers to the DNA strand that complements. The primer has been attached at $60^{\circ} \mathrm{C}$ for 45 seconds. The last stage is extension or elongation. The elongation stage which has been carried out at $72^{\circ} \mathrm{C}$ for 5 minutes. DNA will be extended to a length of $149 \mathrm{bp}$. This stage will run for 40 cycles. Visualized about PCR results to determine DNA presence. Visualization used gel electrophoresis which made from 2 grams agarose powder and $100 \mathrm{~mL}$ of TAE buffer. Positive control (Figure 2) after visualized shows the presence of a band at of $149 \mathrm{bp}$. In visualization 22 samples of food, there was no band found, only the primer residue at the bottom of the electrophoresis gel. Based on the results, shown that the method used has been able to detect the $c y t b$ gene in food products. However, detection of porcine contaminant should be carried out using more modern PCR method such as RT-PCR in order to obtain comprehensive results, especially when aimed at formulating a policy. This has been done by Priyanka (2017) who use beef sausages from traditional and modern markets in Yogyakarta. The results of porcine DNA amplification in 9 sausage samples showed that 8 of them contained porcine DNA and had 95\% homology with Sus scrofa.

Based on that information, further research is needed to examine porcine contaminant in samples of sausages, meatballs or other processed foods using more samples and other methods and primers. Other methods that can be used include Multiplex PCR as is done by Kitpipit et al. (2014) and Ali et al. (2015), the gold standard method of DNA test Real time PCR, to ddPCR as is done by Floren et al. (2015). This is intended to obtain specific, sensitive, and comprehensive results.

\section{Conclusion}

On 22 samples of food product around UIN Sunan Ampel Surabaya were not found any porcine contamination based on PCR method. As shown in PCR visualization results, there is no band at 149 bp which indicates the length of $c y t b$ gene primer. However, examination of porcine contaminant should be carried out by other methods and other target primer in order to obtain comprehensive results, especially when aimed at policy formulating.

\section{Acknowledgements}

Our gratitude go to LPPM for research support facilities. The facilities about Research Laboratory, Genetics and Tissue Culture - Integrated Laboratory of UIN Sunan Ampel Surabaya.

\section{References}

Ali, M. E., Hashim, U., Mustafa, S., Man, Y. C., Dhahi, T. S., Kashif, M., ... \& Abd Hamid, S. B. (2012). Analysis of pork adulteration in commercial meatballs targeting porcine-specific mitochondrial cytochrome $\mathrm{b}$ gene by TaqMan probe real-time polymerase chain reaction. Meat 
Science, 91(4), 454-459.

Ali, M. E., Hashim, U., Mustafa, S., \& Man, Y. B. C. (2012). Swine-specific PCR-RFLP assay targeting mitochondrial cytochrome $\mathrm{B}$ gene for semiquantitative detection of pork in commercial meat products. Food Analytical Methods, 5(3), 613-623.

Ali, M. E., Razzak, M. A., Abd Hamid, S. B., Rahman, M. M., Al Amin, M., \& Abd Rashid, N. R. (2015). Multiplex PCR assay for the detection of five meat species forbidden in Islamic foods. Food Chemistry, 177, 214-224.

Adzakiyyi, M. L., Susilowati, T., Rokhim, S., \& Rachmawati, Y. (2020). Sus sp. DNA Encoding cyt b Gene Detection Test on Meat Grinding Samples Using Conventional PCR. Indonesian Journal of Halal Research, 2(2), 40-45.

Asy'ari, H. (2011). Kriteria makanan halal dalam perspektif Ibnu Hazm dan MUI. Jakarta: UIN Syarif Hidayatullah.

Baihaqi, M., Rachmawati, Y., Rokhim, S., Munir, M., \& Hamidah, L. (2019). Real Time PCR Assays for Detection and Quantification of Porcine DNA in Meat Milling Samples. ICOST: EAI Proceeding, 1-7.

Fatchiyah, A. E. L., Widyarti, S., \& Rahayu, S. (2011). Biologi Molekular Prinsip Dasar Analisis. Jakarta: Erlangga.

Fibriana, F., Widianti, T., \& Retnoningsih, A. (2010). Deteksi Kandungan Daging Babi pada Bakso yang Dijajakan di Pusat Kota Salatiga Menggunakan Teknik Polymerase Chain Reaction. Biosaintifika, 2(1), 10-17.

Floren, C., Wiedemann, I., Brenig, B., Schütz, E., \& Beck, J. (2015). Species identification and quantification in meat and meat products using droplet digital PCR (ddPCR). Food Chemistry, $173,1054-1058$.

Kitpipit, T., Sittichan, K., \& Thanakiatkrai, P. (2014). Direct-multiplex PCR assay for meat species identification in food products. Food Chemistry, 163, 77-82.

Kumar, D., Singh, S. P., Karabasanavar, N. S., Singh, R., \& Umapathi, V. (2014). Authentication of beef, carabeef, chevon, mutton and pork by a PCR-RFLP assay of mitochondrial cyt b gene. Journal of Food Science and Technology, 51(11), 3458-3463.

Monteil-Sosa, J. F., Ruiz-Pesini, E., Montoya, J., Roncales, P., Lopez-Perez, M. J. \& Perez-Martos, A. (2000). Direct and Highly Species-Specific Detection of Pork Meat and Fat in Meat Products by PCR Amplification of Mitochondrial DNA. Journal of Argicultural and Food Chemistry, 48(1), 2829-2832.

Primasari, A. (2011). Sensitivitas Gen Sitokrom B (Cyt b) Sebagai Marka Spesifik pada Genus Rattus dan Mus Untuk Menjamin Keamanan Pangan Produk Asal Daging. Bogor: Institut Pertanian Bogor

Priyanka, V. A. (2017). Deteksi Cemaran Daging Babi Pada Produk Sosis Sapi di Kota Yogyakarta Dengan Metode Polymerase Chain Reaction. Yogyakarta: Universitas Atmajaya.

Puspitasari, R. L., Elfidasari, D., Perdana, A. T. (2019). Deteksi Kandungan Babi pada Makanan Berbahan Dasar Daging di Kampus Universitas Al Azhar Indonesia. Jurnal Al-Azhar Indonesia Seri Sains dan Teknologi, 5(2), 66-69.

Sulandari, S., \& Zein, M. S. (2003). Panduan Praktis Laboratorium DNA. Bogor: Bidang Zoologi LIPI.

Wardani, A. K., \& Sari, E. P. K. (2015). Deteksi Molekuler Cemaran Daging Babi Pada Bakso Sapi di Pasar Tradisional Kota Malang Menggunakan PCR (Polymerase Chain Reaction). Jurnal Pangan dan Agroindustri, 3(4).

Yusop, M. H. M., Mustafa, S., Man, Y. B. C., Omar, A. R., \& Mokhtar, N. F. K. (2012). Detection of raw pork targeting porcine-specific mitochondrial cytochrome $\mathrm{B}$ gene by molecular beacon probe real-time polymerase chain reaction. Food Analytical Methods, 5(3), 422-429.

Yusuf, Z. K. (2010). Polymerase Chain Reaction (PCR), Saintek, 5(6). 